\title{
Comprehensive Review of Tolypocladium and Description of a Novel Lineage from Southwest China
}

\author{
Feng-Ming Yu ${ }^{1,2,3}$, Kandawatte Wedaralalage Thilini Chethana ${ }^{1,2}$, De-Ping Wei ${ }^{1,2}$, Jian-Wei Liu ${ }^{1,2,4}$, \\ Qi Zhao ${ }^{3,5,6,7}$, Song-Ming Tang ${ }^{1,2,8}, \mathrm{Lu} \mathrm{Li}^{3,5}$ and Kevin David Hyde ${ }^{1,2,3, *}$ \\ 1 Center of Excellence in Fungal Research, Mae Fah Luang University, Chiang Rai 57100, Thailand; \\ 6171105508@lamduan.mfu.ac.th (F.-M.Y.); kandawatte.thi@mfu.ac.th (K.W.T.C.); \\ wei_deping@cmu.ac.th (D.-P.W.); liujianwei@mail.kib.ac.cn (J.-W.L.); \\ 6171105516@lamduan.mfu.ac.th (S.-M.T.) \\ 2 School of Science, Mae Fah Luang University, Chiang Rai 57100, Thailand \\ 3 Key Laboratory for Plant Diversity and Biogeography of East Asia, Kunming Institute of Botany, \\ Chinese Academy of Sciences, Kunming 650201, China; zhaoqi@mail.kib.ac.cn (Q.Z.); \\ lilu@mail.kib.ac.cn (L.L.) \\ 4 The Germplasm Bank of Wild Species, Yunnan Key Laboratory for Fungal Diversity and Green Development, \\ Kunming Institute of Botany, Chinese Academy of Sciences, Kunming 650201, China \\ 5 Yunnan Key Laboratory for Fungal Diversity and Green Development, Kunming 650201, China \\ 6 Institute of Applied Fungi, Southwest Forestry University, Kunming 650224, China \\ 7 School of Chemical Engineering, Guizhou Institute of Technology, Guiyang 550003, China \\ 8 Biotechnology and Germplasm Resources Institute, Yunnan Academy of Agricultural Science, \\ Kunming 650205, China \\ * Correspondence: kdhyde3@gmail.com
}

Citation: Yu, F.-M.; Thilini Chethana, K.W.; Wei, D.-P.; Liu, J.-W.; Zhao, Q.; Tang, S.-M.; Li, L.; Hyde, K.D. Comprehensive Review of Tolypocladium and Description of a Novel Lineage from Southwest China. Pathogens 2021, 10, 1389. https:// doi.org/10.3390/pathogens10111389

Academic Editor: László Kredics

Received: 14 September 2021

Accepted: 20 October 2021

Published: 27 October 2021

Publisher's Note: MDPI stays neutral with regard to jurisdictional claims in published maps and institutional affiliations.

Copyright: (c) 2021 by the authors. Licensee MDPI, Basel, Switzerland. This article is an open access article distributed under the terms and conditions of the Creative Commons Attribution (CC BY) license (https:// creativecommons.org/licenses/by/ $4.0 /)$.
Abstract: Tolypocladium, a diverse genus of fungicolous fungi belonging to Ophiocordycipitaceae, includes saprotrophic soil inhabitants, plant endophytes and pathogens of insects, nematodes, rotifers, and parasites of truffle-like fungi. Here, we review the research progress achieved for Tolypocladium regarding its taxonomy, species diversity, geographic distribution, host affiliations and ecological diversity. Furthermore, an undescribed taxon from China was established using morphology and multi-gene phylogeny. Tolypocladium inusitaticapitatum is introduced as a new species parasitizing ectomycorrhizal Elaphomyces species. It is diagnosed by its irregularly enlarged fertile heads and lemon, yellow-to-dark-brown, smooth and nearly cylindrical stipe. Phylogenetic analyse based on SSU, LSU, ITS, TEF1- $\alpha$ and RPB2 sequence data showed T. inusitaticapitatum to be an independent lineage separated from T. flavonigrum in the clade comprising T. capitatum, T. fractum and T. longisegmentatum. A key for identifying the sexual Tolypocladium species is also provided.

Keywords: new taxon; diversity; ecology; host shift; multi-gene; mycoparasite; taxonomic key

\section{Introduction}

Fungal species establish antagonistic to mutualistic associations with numerous prokaryotes and eukaryotes, including bacteria, algae, animals, plants and other fungi [1] More than 1500 fungicolous taxa are widely distributed in aquatic and terrestrial ecosystems from tropical to polar regions [1]. Their hosts are ecologically diverse across the fungal kingdom. Truffle-like fungi are hypogeous and taxonomically distributed in Ascomycota and Basidiomycota [2]. Some truffle-like fungi were reported to be hosts of fungicolous species belonging to Absidia Tiegh., Battarrina (Sacc.) Clem. and Shear, Entoloma P. Kumm., Hypocrea Fr., Hypomyces (Fr.) Tul. and C. Tul., Hypoxylon Bull., Melanospora Corda, Sporothrix Hektoen and C.F. Perkins, and Tolypocladium W. Gam [1,3].

Tolypocladium W. Gams was established based on three soil-inhabiting asexual species: Tolypocladium cylindrosporum W. Gams, T. geodes W. Gams and T. inflatum W. Gams (the type species) [4]. Hodge and colleagues linked the asexual T. inflatum to the sexual species 
Cordyceps subsessilis Petch [5]. Subsequently, Sung and colleagues introduced the sexual genus Elaphocordyceps G.H. Sung and Spatafora and linked it to the asexual Tolypocladium and some species within Verticillium Nees based on multigene phylogeny [6]. Moreover, Sung and colleagues transferred the species of Cordyceps sensu lato that parasitize ectomycorrhizal Elaphomyces (18 species and two forma), cicada nymphs (C. inegoënsis Kobayasi, C. paradoxa Kobayasi, and C. toriharamontana Kobayasi) and beetle larvae (C. subsessilis) to Elaphocordyceps [6]. Chaunopycnis was established by Gams to accommodate Ch. alba, which resembles Tolypocladium in conidiogenesis [7]. Later, Quandt and colleagues synonymized Chaunopycnis and Elaphocordyceps under Tolypocladium, following the "One Fungus One Name" rule, as Tolypocladium is much more widely known, medicinally important and an older genus [4,6-8].

Most Tolypocladium species are Elaphomyces-attacking mycoparasites, except for few entomopathogens $[9,10]$. The evolution of host specificity and the dynamics of host jumping were investigated by several researchers using molecular data [6,8,11-15]. Nikoh and Fukatsu inferred that there was a shift from entomoparasitism to mycoparasitism during the evolution of the Cordyceps-like fungi [11]. However, with the addition of more gene regions and taxa, insect pathogens such as T. paradoxum and T. inflatum were found to be clustered with some parasites on truffles. The researchers explained that the ancestral ecology was a truffle parasitism, with multiple switches to insect pathogenicity $[6,8,12]$. Notably, the interspecific relationships of closely related Tolypocladium species are weakly supported and inconsistently resolved with different datasets $[6,8,13,14]$. To compensate for the shortage of limited loci, Quandt and colleagues performed genome-scale phylogenetic analyses based on two entomopathogens (T. ophioglossoides and T. capitatum) and two mycoparasites (T. inflatum and T. paradoxum) and demonstrated that truffle parasites form a monophyletic clade. They suggest that this lineage is derived as a result of a single ecological transition or host-jumping from insects to fungi [15].

A successful infection caused by fungal pathogens generally undergoes host recognition, attachment, and then infection and degradation, depending on the gene content, expression, or regulation [16]. Tolypocladium is recognized as an ideal candidate for investigating the mechanisms associated with host-jumping [15,16]. Quandt and colleagues researched the set of genes that are differentially regulated in Tolypocladium species during their first encounter with their hosts [16]. They found that PTH11-related G-proteincoupled receptors (GPCRs), predicted to be involved in host recognition, were up-regulated in T. ophioglossoides when grown on media containing insect cuticles [16]. Furthermore, a divergent chitinase and an adhesin gene, Mad1, were significantly up-regulated on media containing Elaphomyces [16]. According to the transcriptomic data, genes involved in redox reactions and transmembrane transport were the most overrepresented during T. ophioglossoides growth on Elaphomyces media. However, the genes involved in secondary metabolism may not be necessary for the parasitism of truffles as their products are only highly expressed during the growth on insect tissues [16].

To date, Tolypocladium comprises 41 species (Table 1) with a cosmopolitan distribution $[2,17]$. Some of them produce various secondary metabolites, such as cyclosporin, efrapeptins, ophiocordin and ophiosetin [18]. They have been widely used in biopharmaceuticals and biocontrol [18]. During an investigation of fungi in Yunnan Province, Southwest China, an undescribed Tolypocladium species was discovered on Elaphomyces $\mathrm{sp}$. The present study aimed to (i) systematically review species diversity, hosts/habitat, geographical distribution and host affiliations of Tolypocladium species, (ii) broaden the knowledge of species diversity and host shifts in Tolypocladium species, (iii) refine the diagnostic characters of the interspecific classification of Tolypocladium in sexual morphs and provide a taxonomic key. 
Table 1. Species diversity, hosts/habitats and geographic distribution of Tolypocladium species.

\begin{tabular}{|c|c|c|}
\hline Fungal Name & Hosts/Isolated From & Known Distribution \\
\hline T. album & Soil, sapwood of Hevea brasiliensis & $\begin{array}{l}\text { Colombia, France, Scotland, Sri Lanka, Sweden, } \\
\text { The Netherlands [7], Peru [12] }\end{array}$ \\
\hline T. amazonense & Sapwood of Hevea brasiliensis and H. guianensis & Peru [12] \\
\hline${ }^{*}$ T. capitatum & Elaphomyces granulatus, E. japonicus, Elaphomyces sp. & $\begin{array}{l}\text { Asia (China (Taiwan, Yunnan), Japan), Europe (France, Holland, } \\
\text { Hungary), North America (Canada, U.S.A.) }[9,10,19-22]\end{array}$ \\
\hline T. cylindrosporum & $\begin{array}{l}\text { Soil, sewage, peat, roots of Picea mariana; Plecia nearctica, } \\
\text { larvae of Aedes sierrensis, larvae of Aedes australis, larvae } \\
\text { and pupae of Lucilia sericata, Drosophila larvae (Diptera) }\end{array}$ & $\begin{array}{l}\text { Brazil, China, Czech, England, New Zealand, Nepal, The } \\
\text { Netherlands, The North Island, U.S.A. [4,23-27] }\end{array}$ \\
\hline${ }^{*}$ T. delicatistipitatum & E. asahimontanus & China (Jiangxi) [28], Japan [10] \\
\hline${ }^{*}$ T. dujiaolongae & Cicada nymphs & China (Anhui, Fujian, Jiangsu, Jiangxi, Zhejiang) [29] \\
\hline T. endophyticum & Living sapwood of Hevea brasiliensis and H. guianensis & Brazil, Mexico, Peru [12] \\
\hline T. extinguens & Larvae of Arachnocampa luminosa (Diptera) & New Zealand [24] \\
\hline${ }^{*}$ T. fractum & E. appalachiensis & U.S.A. (Tennessee) [9] \\
\hline${ }^{*}$ T. flavonigrum & Elaphomyces sp. & Thailand [30] \\
\hline${ }^{*}$ T. fumosum & $\begin{array}{l}\text { Cocooned pupa of bagworm moth (Psychidae) buried } \\
\text { among mosses }\end{array}$ & Poland [31] \\
\hline T. geodes & Soil & $\begin{array}{l}\text { Austria, Canada, China, Denmark, England, } \\
\text { The Netherlands }[4,23,26]\end{array}$ \\
\hline${ }^{*}$ T. guangdongense & Elaphomyces sp. & China (Guangdong) [32] \\
\hline${ }^{*}$ T. inegoense & Cicada nymphs (e.g., Hyalessa maculaticollis) & China (Fujian, Taiwan) [33], Japan [34], Korea [6] \\
\hline${ }^{*}$ T. inflatum & $\begin{array}{l}\text { Larvae of Scarabaeidae (e.g., Aphodiinae, Rutelinae) (sexual } \\
\text { morph); soil, humus, Picea glauca, roots of P. mariana, } \\
\text { surface of Mycobates sp. (Acari, Mycobatidae), sclerotium of } \\
\text { Ophiocordyceps gracilis (asexual morph) }\end{array}$ & $\begin{array}{l}\text { Sexual morph: Japan, U.S.A. (Tennessee, North Carolina, Michigan, } \\
\text { New York, Washington) [5]; asexual morph: Austria, Canada, China, } \\
\text { Nepal, Germany, U.S.A. }[4,23,26,35]\end{array}$ \\
\hline${ }^{*}$ T. intermedium & E. granulatus, E. subvariegatus & Japan, U.S.A. (New York) $[10,36]$ \\
\hline${ }^{*}$ T. japonicum & E. granulatus, E. japonicus, E. neoasperulus & Austria, Japan [10], China (Guizhou, Taiwan) [28,37] \\
\hline${ }^{*}$ T. jezoense & E. anthracinus, E. miyabeanus, E. nopporensis & Japan [10] \\
\hline T. lignicola & Rotting wood (parasitic in bdelloid rotifers) & Canada (Ontario) [38] \\
\hline${ }^{*} \mathrm{~T}$. longisegmentatum & E. granulatus, E. japonicus, E. muricatus, Elaphomyces sp. & $\begin{array}{l}\text { Asia (China (Jilin), Japan), Europe (England, Germany, Holland), } \\
\text { North America (Canada, Mexico, U.S.A.) }[9,10,20,21,39]\end{array}$ \\
\hline T. microsporum & Soil & Canada, Germany, The Netherlands, U.S.A. [23] \\
\hline${ }^{*}$ T. minazukiense & Elaphomyces sp. & Japan [40] \\
\hline${ }^{*}$ T. miomoteanum & Elaphomyces sp. & Japan [40] \\
\hline T. nubicola & Soil & Canada (Alberta), China (Guizhou) [23,41] \\
\hline${ }^{*}$ T. ophioglossoides & $\begin{array}{l}\text { E. granulatus, E. japonicus, E. muricatus, E. shimizuensis, E. } \\
\text { titibuensis, and Elaphomyces sp. }\end{array}$ & $\begin{array}{l}\text { Commonly in Asia (e.g., China (Guangxi, Jiangsu, Jiangxi, Jilin, } \\
\text { Shandong, Sichuan, Taiwan, Yunnan), Japan, Korea), Europe and } \\
\text { North America }[9,10,42-44]\end{array}$ \\
\hline T. ovalisporum & Lichen Polycauliona regalis & Antarctica (King George Island) [45] \\
\hline${ }^{*}$ T. paradoxum & $\begin{array}{l}\text { Cicada nymphs (e.g., Platypleura kaempferi, } \\
\text { Graptopsaltria nigrofuscata) }\end{array}$ & China (Hainan, Yunnan) [46], Japan, Koera [34,47] \\
\hline T. pustulatum & Soil, twigs in oak forest, and living leaf of Kalmia latifolia & Mexico (Nuevo León), Spain (Cádiz), U.S.A. (New Jersey) [48] \\
\hline${ }^{*}$ T. ramosum & Elaphomyces sp. & China (Anhui, Fujian, Gansu, Guangdong) $[44,49,50]$ \\
\hline${ }^{*}$ T. rouxii & E. variegatus & France [51] \\
\hline T. sinense & Stroma and sclerotium of Ophiocordyceps sinensis & China (Yunnan) [52] \\
\hline${ }^{*}$ T. szemaoense & E. granulatus & China (Yunnan) [53] \\
\hline${ }^{*}$ T. tenuisporum & Host not found (probably Elaphomyces sp.) & U.S.A. (Pennsylvania) [9] \\
\hline T. terricola & Soil & Finland [54] \\
\hline${ }^{*}$ T. toriharamontanum & Cicada nymph (Auritibicen bihamatus) & Japan [34] \\
\hline T. trigonosporum & Rotting stump (parasitic on bdelloid rotifers) & Canada (Nova Scotia) [55] \\
\hline T. tropicale & Sapwood and leaf tissue of Hevea brasiliensis & Mexico, Peru [12] \\
\hline T. tundrense & Soil & Canada (Northwest Territories) [23] \\
\hline${ }^{*}$ T. valliforme & E. granulatus, Elaphomyces sp. & Canada (Ontario), U.S.A. (Carolina, New York, Virginia) [9] \\
\hline${ }^{*}$ T. valvatistipitatum & E. granulatus, E. neoasperulus & Japan [10] \\
\hline${ }^{*}$ T. virens & Elaphomyces sp. & Japan [56] \\
\hline
\end{tabular}

* indicates sexual morphs (25 species). 


\section{Results}

\subsection{Phylogenetic Placement}

The combined SSU, LSU, ITS, TEF1- $\alpha$ and RPB2 sequence dataset comprised 35 species, containing 5384 nt (SSU: 1-1536, LSU: 1537-2441, ITS: 2442-3306, TEF1- $\alpha$ : 3307-4264, RPB2: 4265-5384) after the alignment (including gaps). Among them, $3731 \mathrm{bp}$ (base pairs) were conserved, 378 variable, parsimony-uninformative, and 1275 parsimony-informative. The ML and BI analyses resulted in phylogenetic trees with a similar topology. The ML tree with a final log-likelihood of -27186.604 is shown in Figure 1. Specimens HKAS 112152 and HKAS 112153 clustered together and formed a distinct clade with strong support values $(\mathrm{SH}-\mathrm{aLRT}=100, \mathrm{UFB}=100$ and BIPP $=1)$, indicating a conspecific relationship. These two specimens separated from other Tolypocladium species with SH-aLRT $=90.2$ and BIPP $=0.98$ support values. However, their LSU sequences showed an 11 bp difference $(1.28 \%)$ across the $862 \mathrm{bp}$ region, contributing to the different branch lengths in the phylogenetic tree. Based on the available molecular data for Tolypocladium species, some differences are known to occur due to intraspecific variations in the LSU sequences, ranging from 0.25 to $1.28 \%$ (Table 2).

Table 2. Intraspecific base-pair differences in LSU genes among Tolypocladium species.

\begin{tabular}{|c|c|c|c|c|c|c|c|c|c|c|c|c|c|}
\hline Species & Locus & 522 & 532 & 855 & & & & & & & & & Ratio \\
\hline T. album & $\begin{array}{c}\text { CBS 393.89 } \\
\text { GB5502 }\end{array}$ & $\begin{array}{l}\mathrm{C} \\
\mathrm{T}\end{array}$ & $\begin{array}{l}\mathrm{C} \\
\mathrm{T}\end{array}$ & $\begin{array}{l}\mathrm{C} \\
-\end{array}$ & & & & & & & & & $0.35 \%(3 / 870 \mathrm{bp})$ \\
\hline Species & $\begin{array}{r}\text { Locus } \\
\end{array}$ & 20 & 21 & 23 & 24 & 25 & 27 & & & & & & Ratio \\
\hline T. inflatum & $\begin{array}{l}\text { OSC } 71235^{\#} \\
\text { CBS } 127302 \\
\end{array}$ & $\begin{array}{l}\mathrm{A} \\
\mathrm{G} \\
\end{array}$ & $\begin{array}{l}\mathrm{G} \\
\mathrm{A}\end{array}$ & $\begin{array}{l}\text { A } \\
-\end{array}$ & $\begin{array}{l}\text { A } \\
- \\
\end{array}$ & $\begin{array}{l}\mathrm{C} \\
- \\
\end{array}$ & $\begin{array}{l}\mathrm{A} \\
\mathrm{C}\end{array}$ & & & & & & $0.76 \%(6 / 794 \mathrm{bp})$ \\
\hline Species & Locus & 48 & 434 & & & & & & & & & & Ratio \\
\hline T. ophioglossoides & $\begin{array}{l}\text { CBS } 1002399^{\#} \\
\text { NBRC } 106330\end{array}$ & $\begin{array}{l}\mathrm{C} \\
\mathrm{T} \\
\end{array}$ & $\begin{array}{l}\mathrm{C} \\
\mathrm{T} \\
\end{array}$ & & & & & & & & & & $0.25 \%(2 / 816 \mathrm{bp})$ \\
\hline Species & \begin{tabular}{l|l} 
Locus \\
\end{tabular} & 164 & 382 & 405 & 433 & 442 & 479 & 496 & 524 & & & & Ratio \\
\hline T. paradoxum & $\begin{array}{c}\text { NBRC } 106958^{\#} \\
\text { NBRC } 100945\end{array}$ & $\begin{array}{l}\mathrm{T} \\
\mathrm{C}\end{array}$ & $\begin{array}{l}\mathrm{C} \\
\mathrm{T}\end{array}$ & $\begin{array}{l}\mathrm{G} \\
\mathrm{A}\end{array}$ & $\begin{array}{l}\mathrm{C} \\
\mathrm{T}\end{array}$ & $\begin{array}{l}\mathrm{C} \\
\mathrm{T} \\
\end{array}$ & $\begin{array}{l}\mathrm{C} \\
\mathrm{T}\end{array}$ & $\begin{array}{l}\mathrm{T} \\
\mathrm{C}\end{array}$ & $\begin{array}{l}\mathrm{G} \\
\mathrm{A}\end{array}$ & & & & $0.90 \%(8 / 891 \mathrm{bp})$ \\
\hline Species & Locus & 8 & 37 & 44 & 51 & 81 & 96 & 110 & 124 & 204 & 210 & 402 & Ratio \\
\hline T. inusitaticapitatum & $\begin{array}{l}\text { HKAS } 112152^{\#} \\
\text { HKAS } 112153\end{array}$ & $\begin{array}{l}\mathrm{T} \\
\mathrm{C}\end{array}$ & $\begin{array}{l}\mathrm{T} \\
\mathrm{C}\end{array}$ & $\begin{array}{l}\mathrm{A} \\
\mathrm{G}\end{array}$ & $\begin{array}{l}\mathrm{A} \\
\mathrm{G}\end{array}$ & $\begin{array}{l}\mathrm{A} \\
\mathrm{G}\end{array}$ & $\begin{array}{l}\mathrm{A} \\
\mathrm{G}\end{array}$ & $\begin{array}{l}\mathrm{T} \\
\mathrm{C}\end{array}$ & $\begin{array}{l}\mathrm{T} \\
\mathrm{C}\end{array}$ & $\begin{array}{l}\mathrm{A} \\
\mathrm{G}\end{array}$ & $\begin{array}{l}\mathrm{A} \\
\mathrm{G}\end{array}$ & $\begin{array}{l}\mathrm{G} \\
\mathrm{T}\end{array}$ & $1.28 \%(11 / 862 \mathrm{bp})$ \\
\hline
\end{tabular}

The locus numbers refer to the base-pair positions of the gene sequences, and "\#" represents the reference sequences. Gaps are indicated with ' - '.

Specimens Tolypocladium inusitaticapitatum (China), together with four Tolypocladium species occurring on Elaphomyces spp., i.e., T. capitatum (intercontinental distribution), T. flavonigrum (Thailand), T. fractum (USA) and T. longisegmentatum (intercontinental distribution), formed a monophyletic clade with weak support (SH-aLRT $=81.1, \mathrm{UFB}=82$ and $\mathrm{BIPP}=0.90$. UFB values not shown in the ML tree). Tolypocladium inusitaticapitatum formed a separate clade sister to T. flavonigrum. However, the nucleotide comparison between T. inusitaticapitatum (holotype: HKAS 112152) and T. flavonigrum (holotype: BCC 66576) showed $154 \mathrm{bp}(26.78 \%)$ differences across $575 \mathrm{bp}$ ITS, $87 \mathrm{bp}(9.83 \%)$ differences across $885 \mathrm{bp} \mathrm{LSU}$, and $47 \mathrm{bp}$ (4.99\%) differences across 942 bp TEF1- $\alpha$ (including gaps), respectively. The phylogenetic evidence suggested that these two specimens represent new species.

\subsection{Taxonomy}

Tolypocladium W. Gams, Persoonia 6: 185 (1971); emended by Quandt and colleagues, IMA Fungus 5: 125 (2014).

Index Fungorum number: IF10242; Facesoffungi number: FoF 10425.

Synonyms: Chaunopycnis W. Gams, Persoonia 11: 75 (1980).

Elaphocordyceps G.H. Sung and Spatafora, Stud. Mycol. 57: 36 (2007).

Type species: Tolypocladium inflatum W. Gams 1971. 


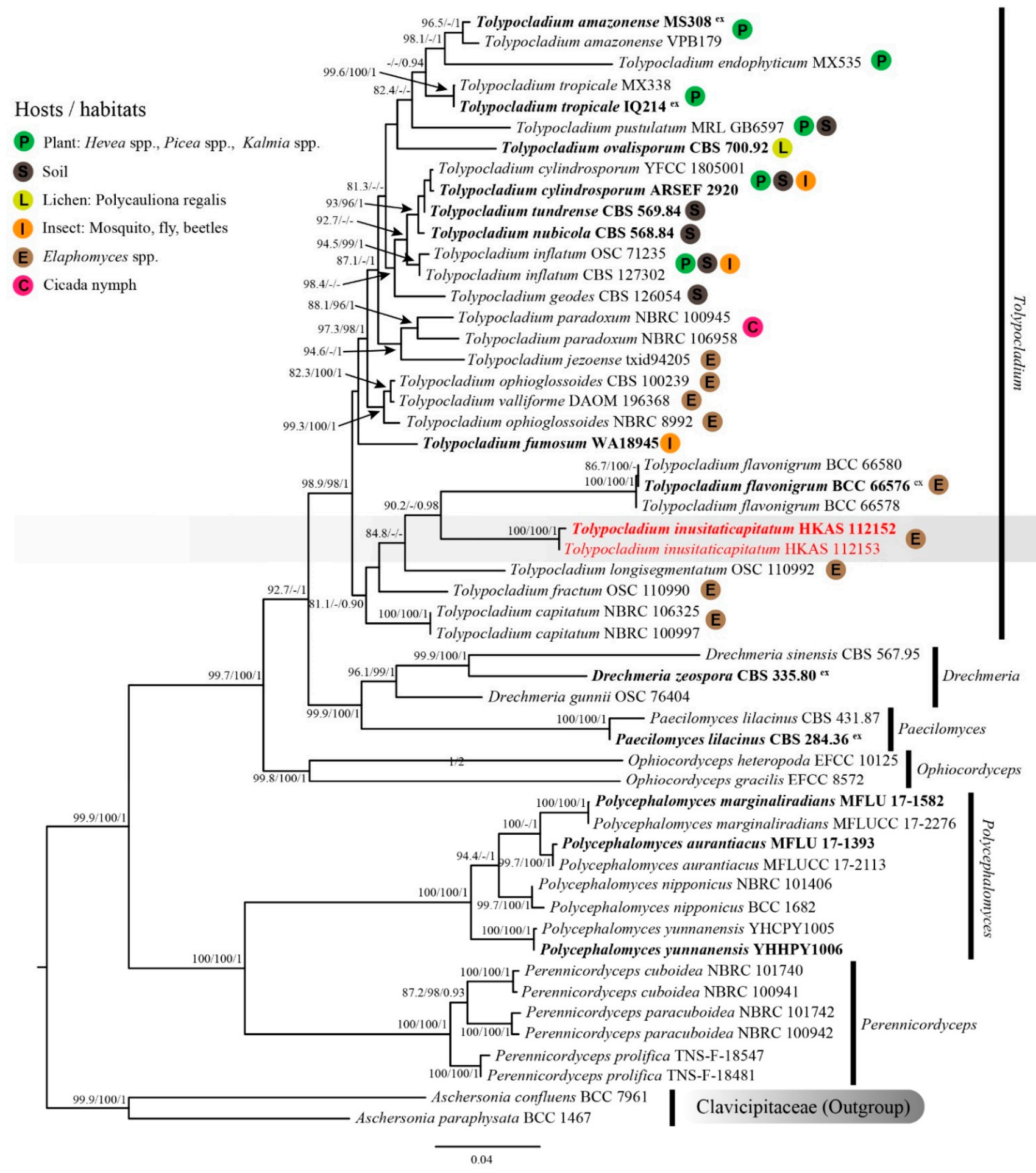

Figure 1. Maximum likelihood (ML) tree of Tolypocladium inusitaticapitatum and its allies within Ophiocordycipitaceae inferred from combined SSU, LSU, ITS, TEF1- $\alpha$ and RPB2 dataset. Bootstrap support values for ML $\geq 80$ of SH-aLRT or 95 of UFB and posterior probability for BI $\geq 0.90$ are indicated above the nodes and separated by '-/-/' (SH-aLRT/UFB/BIPP). Specimens of the current study are given in red. Type specimens are in bold and the superscript 'ex' indicates ex-type.

Morphological characterization: Sexual morph: Stromata arise directly from the host and are sometimes indirectly connected to the host through rhizomorph-like structures. They range from solitary to several and can be simple or branched. Stipe is fibrous to tough, rarely fleshy, dark-brownish to greenish with an olivaceous tint, rarely whitish, cylindrical and enlarges near the fertile part. The fertile part is clavate- to capitate-shaped 
and varies in color. Perithecia are partially to completely immersed, or superficial, or produced on a highly reduced stromatic pad, and ostiolate. Asci are unitunicate and long cylindrical with a thickened apical cap. Ascospores are filiform, approximately as long as asci, multi-septate, typically disarticulate into part-spores, and are occasionally non-disarticulating when mature (e.g., T. ramosum). Part-spores are hyaline, fusiform to cylindrical with round to truncate ends [6,8]. Asexual morph: They are Tolypocladium-, Chaunopycnis-, or Verticillium-like. Colonies are white, cottony and grow slowly on artificial media (e.g., potato dextrose agar, Czapek-Dox agar, malt extract agar, Sabouraud Glucose agar and water agar). Conidiophores usually are short and bear lateral or terminal phialides whorls. Phialides usually are swollen at the base and thin, often with bent necks. Conidia are globose to oval, one-celled, hyaline, smooth, and aggregative in small heads at the tips of the phialides $[4,23]$.

Hosts and habits: Found in terrestrial and humid environments. Species of Tolypocladium parasitize hypogeous Elaphomyces (20 species including the novel species described in this study), cicada nymphs (4 species), beetle larvae (T. inflatum), pupa of the bagworm moth (T. fumosum), mosquito larvae (T. extinguens), and even bdelloid rotifers exposed to air (T. lignicola and T. trigonosporum). Their ascospores/conidia and mycelia survive in soil, or on various humus, rotting wood, plant tissues and surfaces, body surfaces of insects and mites, tissues of Cordyceps and lichens (Table 1).

Species diversity and distribution: Tolypocladium currently consists of 42 species (including the novel species described in this study) distributed worldwide $[2,3,17]$. Seventeen species were recorded from China (Table 1).

\subsection{Description of the Novel Species}

Tolypocladium inusitaticapitatum F.M. Yu, Q. Zhao and K.D. Hyde, sp. nov. Figure 2. Index Fungorum: IF558123; Facesoffungi number: FoF 10407.

Typification: China, Yunnan Province, Lijiang City, Lijiang Alpine Botanic Garden, E100 $10^{\prime} 58.07$, N26$^{\circ} 59^{\prime} 58.35$, alt. 3338 m, 5 Oct 2019, Jian-Wei Liu (HKAS 112152, holotype).

Etymology: The specific epithet 'inusitaticapitatum' is derived from the combination of two Latin words, 1) adjective inusitata (strange, odd) and 2) noun capitatum (head), pointing to the fertile head, which is irregularly expanded.

GenBank accession numbers: ITS = MW 537735, LSU = MW 537718, SSU = MW 537733, TEF1- $\alpha=$ MW 507527, RPB2 = MW 507529.

Description: Asexual morph Stromata 9-11.5 cm high, solitary and simple, arising directly from the fruiting bodies of Elaphomyces sp. Stipe yellow at base, olive-brown to dark brown at the middle part, and yellowish brown at the terminal part. They are $7.5-11.5 \mathrm{~cm}$ long and 7-8.5 mm thick in the widest parts and nearly cylindrical, but the middle part is slightly thicker than the basal and upper parts. The fertile part developed from the terminal of the stipe, and is somewhat ellipsoidal, irregularly barrel-shaped, and sometimes slightly compressed, $1.5-2.0 \mathrm{~cm} \times 1.5-2.0 \mathrm{~cm}$. The surface is decorated with white ascospores released from the mature perithecia, which is olive yellow when immature, and olive to dark brown when mature. The outer layer becomes cracked and the olive internal texture is exposed. Structure of cortex of fertile part: composed of olive brown pseudoparenchymatous tissue and an ectal layer. Perithecia 580-720 $\mu \mathrm{m} \times 180-270 \mu \mathrm{m}(\mathrm{x}=650 \mu \mathrm{m} \times 220 \mu \mathrm{m}$, $n=10)$, crowded, entirely immersed, obovoid, ellipsoidal to pyriform. Ostioles papillate, and are visible (protruding up to $55 \mu \mathrm{m}$ in high) or invisible, lined with periphyses. Asci is $410-510 \mu \mathrm{m} \times 10-15 \mu \mathrm{m}(\mathrm{x}=461 \mu \mathrm{m} \times 13 \mu \mathrm{m}, n=20)$, hyaline, and long cylindrical, with a conspicuously thickened cap (measuring 6.5-7.5 $\mu \mathrm{m} \times 6.0-7.0 \mu \mathrm{m}$ ). Ascospores are approximately as long as asci, and extremely easy to break into part-spores. Part-spores 20-32 $\mu \mathrm{m} \times 3.0-4.5 \mu \mathrm{m}(\mathrm{x}=25 \mu \mathrm{m} \times 3.6 \mu \mathrm{m}, n=20)$, hyaline, cylindrical with rounded ends. Asexual morph: Unknown. 

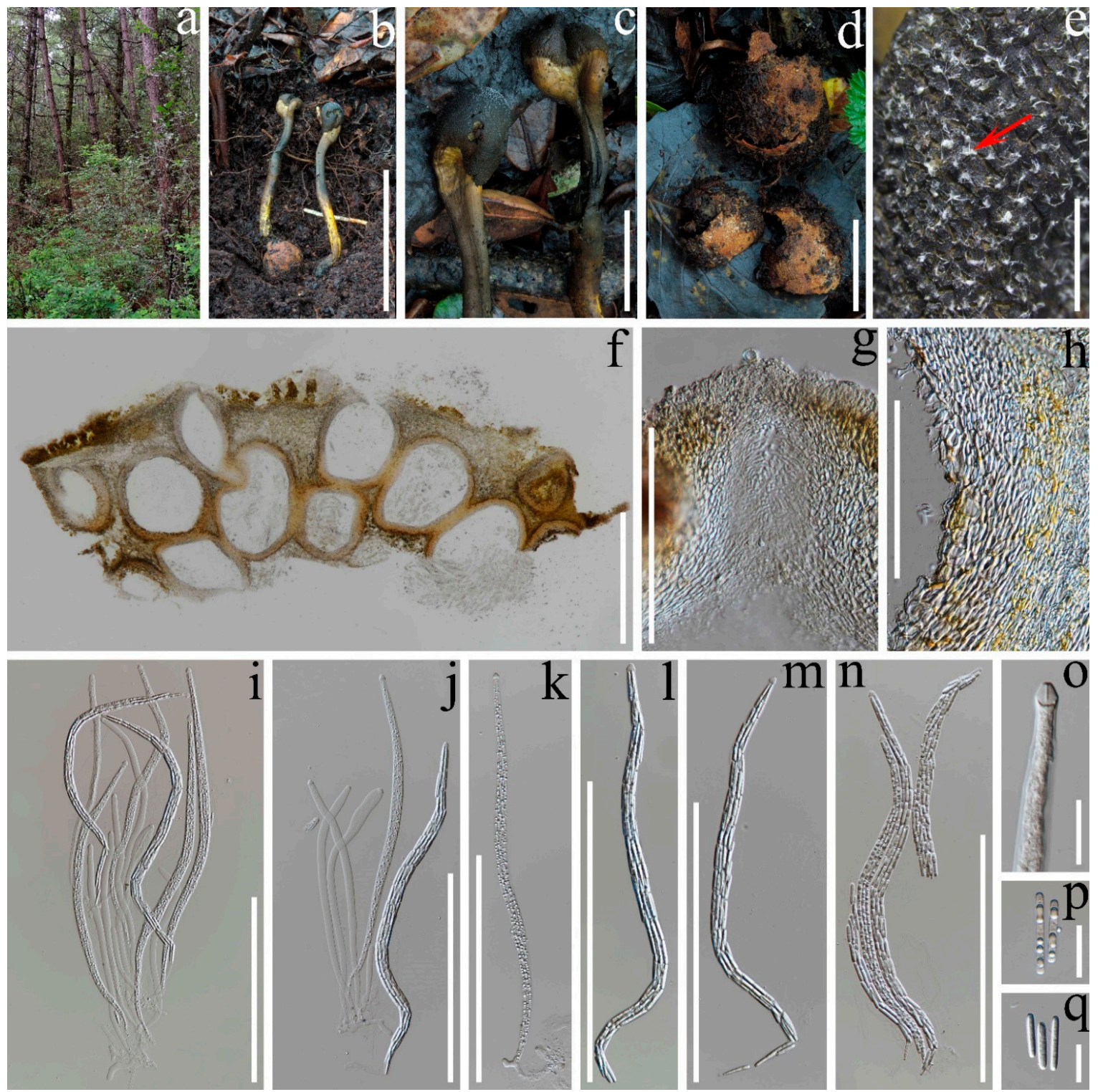

Figure 2. Tolypocladium inusitaticapitatum (holotype: HKAS 112152). (a) Habitat; (b) Stromata arising from the fruiting bodies of Elaphomyces sp.; (c) Fertile heads; (d) Decomposed Elaphomyces sp.; (e) Ascospores released from mature perithecia (shown by a red arrow); (f) Vertical section of a fertile head; (g) Median section across the ostiole of the perithecium; (h) Vertical section across the cortex of a fertile head; (i-n) Asci with ascospores; (o) A thickened cap; (p,q) Part-spores. Bars: $(\mathbf{b})=10 \mathrm{~cm} ;(\mathbf{c}, \mathbf{d})=2 \mathrm{~cm} ;(\mathbf{e})=2 \mathrm{~mm} ;(\mathbf{f})=500 \mu \mathrm{m} ;(\mathrm{g})=50 \mu \mathrm{m} ;(\mathbf{h})=100 \mu \mathrm{m} ;(\mathbf{i}-\mathbf{n})=250 \mu \mathrm{m} ;(\mathbf{o}-\mathbf{q})=20 \mu \mathrm{m}$.

Host and habitat: Directly arising from the fruiting bodies of hypogeous Elaphomyces sp. (Elaphomycetaceae, Eurotiales), in a humid and evergreen broad-leaved rainforest (Lijiang Alpine Botanic Garden), Lijiang, Yunnan Province, P.R. China. As serious degradation has occurred, truffle-like Elaphomyces sp. could not show any morphological evidence of taxonomic significance. Based on the ITS sequence dataset, the phylogenetic analyses showed that the host of T. inusitaticapitatum clustered together with Elaphomyces fuscus M. Shirakawa (Japan) and formed a sister group. However, there are sufficient molecular differences between the host from HKAS 112152 (ITS = MW 513695) and E. fuscus F-a170629 (ITS = LC 500967) to consider them as distinct species.

Known distribution: P.R. China (Yunnan).

Other specimen examined: CHINA, Yunnan, Lijiang, Lijiang Alpine Botanic Garden, alt. 3338 m, 5 October 2019, Jian-Wei Liu (HKAS 112153). 
Notes: Based on the multi-gene phylogeny results, our specimens are closely related to Tolypocladium flavonigrum, known only from Thailand. Both species have stromata directly emerging from the surface of Elaphomyces sp., and capitate fertile heads with the perithecia entirely immersed in a well-differentiated valliforme-like structure [30]. However, T. inusitaticapitatum considerably differs from T. flavonigrum for the olive, yellowishbrown to dark brown fertile part, and is yellow to yellowish-brown at both ends of the stipe compared to the yellow-black to black stromata in T. flavonigrum. Tolypocladium inusitaticapitatum produces obovoid, ellipsoidal to pyriform perithecia, which are markedly distinguished from the elongate-ovoid perithecia produced by T. flavonigrum. Asci and partspores of T. inusitaticapitatum $(410-510 \mu \mathrm{m} \times 10-15 \mu \mathrm{m}, 20-32 \mu \mathrm{m} \times 3.0-4.5 \mu \mathrm{m})$ are larger than those of T. flavonigrum ((318-)330-416(-482) $\mu \mathrm{m} \times 7-8 \mu \mathrm{m}, 2-5 \mu \mathrm{m} \times 1.5-2 \mu \mathrm{m})$ [30].

When comparing Tolypocladium inusitaticapitatum with its other phylogenetic relatives (T. capitatum, T. fractum and T. longisegmentatum), differences were found. Tolypocladium capitatum differs from T. inusitaticapitatum mainly due to its larger perithecia $(900-1100 \mu \mathrm{m} \times 340-430 \mu \mathrm{m})$ and slimmer part-spores (2.5-3 $\mu \mathrm{m}$ wide) [10]. Tolypocladium fractum differs from T. inusitaticapitatum by having smaller stromata $(1.5-2.5 \mathrm{~cm}$ long) and asci $(300-480 \mu \mathrm{m} \times 5-6 \mu \mathrm{m})$ [10]. Tolypocladium longisegmentatum is distinguished from T. inusitaticapitatum by its longer stipe (13 cm long when fresh and up to $11 \mathrm{~cm}$ long when dried) and longer part-spores $((12-) 40-65 \mu \mathrm{m})$ [20]. Morphologically, T. inusitaticapitatum is similar to T. intermedium for the yellow to dark brown stipe but differs in its smaller asci and shorter part-spores (main differences are outlined in Table 3). Regretfully, the molecular data of T. intermedium is not available in GenBank.

Table 3. Main differences between T. intermedium and T. inusitaticapitatum.

\begin{tabular}{|c|c|c|}
\hline & T. intermedium [10] & T. inusitaticapitatum (This Study) \\
\hline Fertile part & Dark reddish brown & Olive brown, yellowish-brown to dark brown \\
\hline Stipe & $\begin{array}{l}\text { Slender, } 6-8.5 \mathrm{~cm} \text { long and } 2-4 \mathrm{~mm} \text { thick, middle } \\
\text { part clearly expanded, surface with many } \\
\text { longitudinal grooves, upper part squamulose }\end{array}$ & $\begin{array}{l}\text { Thicker, } 7.5-11.5 \mathrm{~cm} \text { long and } 7-8.5 \mathrm{~mm} \text { thick, middle } \\
\text { part indistinctly expanded, surface smooth }\end{array}$ \\
\hline Asci & $\begin{array}{c}240-300 \mu \mathrm{m} \times 7-8 \mu \mathrm{m}, \text { caps about } 5 \mu \mathrm{m} \\
\text { in diameter }\end{array}$ & $410-510 \mu \mathrm{m} \times 10-15 \mu \mathrm{m}$, caps $6.5-7.5 \mu \mathrm{m} \times 6.2-7.0 \mu \mathrm{m}$ \\
\hline Part-spores & $\begin{array}{c}\text { Short, } 3-6 \text { (commonly } 4.5) \mu \mathrm{m} \times 1.5-2 \mu \mathrm{m}, \\
\text { truncated at two ends (shape) }\end{array}$ & $\begin{array}{c}\text { Long, 20-32 } \mu \mathrm{m} \times 3.0-4.5 \mu \mathrm{m} \text {, cylindrical with } \\
\text { rounded ends }\end{array}$ \\
\hline Distribution & Japan, USA & P.R. China (Yunnan) \\
\hline
\end{tabular}

\section{Discussion}

Tolypocladium, a generalist genus, has been reported to have diverse lifestyles on a wide range of hosts and environments, including soil, insects, plants, lichens and hypogeal fungi $[6,8]$. The current pattern of host affiliation of Tolypocladium fungi is inferred to be an evolutionary product of intra- and inter-kingdom host shifts [57]. In the last two decades, researchers aimed to infer the evolution of host affiliation within the Tolypocladium, either using a handful of gene loci from dozens to hundreds of taxa, or using genomescale data from fewer taxa $[11,12,15,58]$. To date, the studies on the host-jumping of Tolypocladium have been performed with multigene phylogeny (seven genes from 202 taxa of Hypocreales) [12] and genome-scale phylogeny (1350 genes from 20 taxa of Hypocreales) [15]. The multigene phylogenies supported three hypotheses for Tolypocladium, as follows: (1) the ancestral hosts were fungi (false truffles) $[11,12,57,58]$; (2) there were multiple switches to insect pathogenesis from a mycoparasitic ancestor [8,12,13]; (3) the endophytic lineage has arisen with the contact of plant hosts via mycorrhizal associations or plant-associated insects [12]. However, these conclusions, made from multigene phylogenies, conflict with those made from genome-scale phylogenies, which suggested a single ecological transition from insects to fungi within Tolypocladium [15]. Our phylogenic tree, inferred from five genes of 35 species (Figure 1), resulted in consistent conclusions, similar to those from 
previous multigene phylogenies. Similarly, we encountered several problems, such as phylogenetic conflicts among genetic data partitions and moderate to low support values for some important nodes $[8,12,13]$. Although whole-genome data provide insights that can further resolve the phylogenetic relationships of Tolypocladium $[15,59,60]$, it is still unknown whether those conclusions will be limited by the few available species.

In this study, a novel Tolypocladium species occurring on Elaphomyces sp. is known from its sexual morph. A taxonomic key is also provided for 26 Tolypocladium species. The shape of the fertile part, the connection between the stipe and host, the structure of the cortex of the fertile part, size of part-spores and host affiliation are thought to be characteristic of taxonomic significance for interspecific identification [8-10]. However, there are 16 species whose sexual morphs are still unknown. In addition, the phylogenetic relationships among Tolypocladium species are very sensitive to taxa sampling and loci information [8,15]. Further studies should focus on obtaining more samples from different geographic regions and/or ecological niches, sequencing more markers and even genomic data, building a more robust phylogenetic relationship, and establishing their sexual-asexual morph connections. (Table 4).

Table 4. Key to Sexual Morphs of Tolypocladium species.

\begin{tabular}{|c|c|}
\hline 1. Host insects & 2 \\
\hline $1^{\prime}$. Host hypogeous Elaphomyces spp. & 7 \\
\hline 2. Host beetle or moth larvae & 3 \\
\hline $2^{\prime}$. Host cicada nymphs & 4 \\
\hline 3. Fertile part capitate, with stellate appearance; perithecia ovoid to pear-shaped, $740-760 \times 444-558 \mu \mathrm{m}$ & T. fumosum \\
\hline $3^{\prime}$. Fertile part, strap-shaped pseudostalk; perithecia superficial, narrow flask-shaped, $1000-1500 \times 330-440 \mu \mathrm{m}$ & T. inflatum \\
\hline 4. Stromata arising from underground mycelial membrane or strand; part-spores $3-5 \times 1.5-2 \mu \mathrm{m}$ & T. paradoxum \\
\hline $4^{\prime}$. Stromata arising directly from host & 5 \\
\hline 5. Fertile part elongated, obpyriform; part-spores $1.5-2-2.5 \times 1.5-1.7 \mu \mathrm{m}$ wide & T. toriharamontanum \\
\hline $5^{\prime}$. Fertile part oblong or clavate & 6 \\
\hline 6. Perithecia superficial or apparently half-immersed, pyriform, $520-550 \times 260-280 \mu \mathrm{m}$; part-spores $2.5-3 \times 2 \mu \mathrm{m}$ & T. inegoense \\
\hline $6^{\prime}$. Perithecia wholly immersed, ampullaceous, $(233-) 520-740(-780) \times(250-) 300-330(-360) \mu \mathrm{m}$; part-spores $3-5(-7.0) \times 2-3 \mu \mathrm{m}$ & T. dujiaolongae \\
\hline 7. Stroma attached to host by rhizomorphs & 8 \\
\hline $7^{\prime}$. Stroma arising directly from the host & 12 \\
\hline 8. Part-spores articulate, moniliform, 3-3.5 $\times 2-2.5 \mu \mathrm{m}$ & T. szemaoense \\
\hline $8^{\prime}$. Part-spores with truncate or rounded ends & 9 \\
\hline 9. Stroma capitate & 10 \\
\hline $9^{\prime}$. Stroma solitary or rarely caespitose & 11 \\
\hline 10. Perithecia small, $480-540 \times 225-255 \mu \mathrm{m}$; part-spores large-sized, $18-28 \times 3-5 \mu \mathrm{m}$ & T. delicatistipitatum \\
\hline 10'. Perithecia 770-800 × 350-430 $\mu \mathrm{m}$; part-spores medium-sized, $8-11 \times 1.5-2 \mu \mathrm{m}$ & T. miomoteanum \\
\hline 11. Perithecia oblong with long neck, $700-720 \times 200-250 \mu \mathrm{m}$; part-spores long, $20-30(50) \times 3-4.5 \mu \mathrm{m}$ & T. jezoense \\
\hline $11^{\prime}$. Perithecia ovoid, $550-600 \times 200-300 \mu \mathrm{m}$; part-spores small short rod-shaped, $2.5-5 \times 1.5-2 \mu \mathrm{m}$ & T. ophioglossoides \\
\hline 12. Perithecia superficial, ascospores nonfractured & T. ramosum \\
\hline $12^{\prime}$. Perithecia entirely embedded or ostiole slightly projecting & 13 \\
\hline 13. Fertile part, cortex composed of pseudoparenchymatous peridial layer, and with an ectal layer & 14 \\
\hline $13^{\prime}$. Fertile part, cortex composed of pseudoparenchymatous peridial layer, but without ectal layer & 19 \\
\hline 14. Stromata clavate; perithecia narrowly ovoid, $750-1000 \times 250-300 \mu \mathrm{m}$; part-spores cylindric, $6-8 \times 1-1.5 \mu \mathrm{m}$ & T. tenuisporum \\
\hline 14'. Stromata capitate & 15 \\
\hline 15. Part-spores, larger-sized, more than $20 \mu \mathrm{m}$ long & 16 \\
\hline $15^{\prime}$. Part-spores, less than $20 \mu \mathrm{m}$ long & 17 \\
\hline 16. Part-spores $(12-) 40-65 \times(3-) 4-5 \mu \mathrm{m}$ & T. longisegmentatum \\
\hline $16^{\prime}$. Part-spores $20-32 \times 3.0-4.5 \mu \mathrm{m}$ & T. inusitaticapitatum \\
\hline 17. Part-spores, medium-sized, $(13-) 16(-21) \times 2.5-3 \mu \mathrm{m}$ & T. rouxii \\
\hline $17^{\prime}$. Part-spores, small-sized, $2.5-6 \mu \mathrm{m}$ long & 18 \\
\hline 18. Perithecia elongate-ovoid, $(560-) 567-697(-750) \times(200-) 206-248(-250) \mu \mathrm{m}$; part-spores $2-5 \times 1.5-2 \mu \mathrm{m}$ & T. flavonigrum \\
\hline $18^{\prime}$. Perithecia ovoid, $450-540 \mu \mathrm{m} \times 230-260 \mu \mathrm{m}$; part-spores $3-6$ (commonly 4.5$) \times 1.5-2 \mu \mathrm{m}$ & T. intermedium \\
\hline 19. Stromata clavate & 20 \\
\hline 19'. Stromata capitate & 21 \\
\hline 20. Perithecia small, $245-495 \mu \mathrm{m}$ long, deeply embedded; asci short, $195-270 \mu \mathrm{m}$ long & T. guangdongense \\
\hline $20^{\prime}$. Perithecia $500-550 \mu \mathrm{m}$ long, ostiola slightly projecting; asci $330-370 \mu \mathrm{m}$ long & T. japonicum \\
\hline 21. Perithecia large, more than $900 \mu \mathrm{m}$ long & 22 \\
\hline $21^{\prime}$. Perithecia medium-sized, $400-700 \mu \mathrm{m}$ long & 23 \\
\hline 22. Perithecia ovoid, $900-1100 \times 340-430 \mu \mathrm{m}$; part-spores cylindric or somewhat fusoid, $18-27$ (commonly 24$) \times 2.5-3 \mu \mathrm{m}$ & T. capitatum \\
\hline $22^{\prime}$. Perithecia ampullaceous, $900-930 \times 220-250 \mu \mathrm{m}$; part-spores fusoid, $16-18 \times 3 \mu \mathrm{m}$ & T. minazukiense \\
\hline 23. Stipe slender, less than $1.0 \mathrm{~mm}$ thick & 24 \\
\hline $23^{\prime}$. Stipe thick, columnar, $1.0-6.0 \mathrm{~mm}$ thick & 25 \\
\hline 24. Perithecia $500-600 \times 250-350 \mu \mathrm{m}$; part-spores $2-5 \times 1.5-2 \mu \mathrm{m}$ & T. fractum \\
\hline $24^{\prime}$. Perithecia $400 \times 250 \mu \mathrm{m}$; part-spores $6 \times 1.5 \mu \mathrm{m}$ & T. virens \\
\hline 25. Asci $10-12 \mu \mathrm{m}$ wide; part-spores medium-sized, $7.5-16 \times 2.5-3 \mu \mathrm{m}$ & T. valvatistipitatum \\
\hline $25^{\prime}$. Asci slender, $6-8 \mu \mathrm{m}$ wide; part-spores small-sized, $3-8 \times 2 \mu \mathrm{m}$ & T. valliforme \\
\hline
\end{tabular}




\section{Materials and Methods}

\subsection{Collections and Morphology}

Tolypocladium specimens, including their underground host Elaphomyces sp., were collected in an evergreen broad-leaved forest in Lijiang Alpine Botanic Garden, Lijiang City, Yunnan Province, China. The specimens were examined as described in Senanayake and colleagues with the following modifications [61]. Colour codes were recorded following those of Kornerup and Wanscher [62]. Specimens were deposited at the Herbarium of Cryptogams Kunming Institute of Botany, Chinese Academy of Sciences, Kunming, China (HKAS, KUN).

\subsection{DNA Extraction, PCR Amplification and Sequencing}

The genomic DNA was extracted from the dried materials following the method described by Dissanayake and colleagues [63]. Fertile tissues from the parasitic fungi and the peridium of the host mushroom were used to extract DNA. Primer pairs ITS1F/ITS4 [64], LR0R/LR5 [65,66], PNS1/NS8 [64], TEF1- $\alpha$ 983F/TEF1- $\alpha$ 2218R [67] and fRPB2-5F/fRPB27R [68] were used for the amplification of the internal transcribed spacer region ITS1-5.8SITS2 (ITS), the large subunit rDNA (LSU), the small subunit rDNA (SSU), the translation elongation factor 1- $\alpha(T E F 1-\alpha)$ gene and RNA polymerase II second-largest subunit (RPB2), respectively. PCR reaction was performed in a $25 \mu \mathrm{L}$ reaction volume, comprising $12.5 \mu \mathrm{L}$ Taq PCR Master Mix (Abmgood, Richmond, BC, Canada), $1 \mu \mathrm{L}$ forward primer, $1 \mu \mathrm{L}$ reverse primer, $2 \mu \mathrm{L}$ DNA template and $8.5 \mu \mathrm{L}$ ddH2O. For ITS, LSU, SSU and RPB2, PCR reaction conditions were as follows: $5 \mathrm{~min}$ at $94{ }^{\circ} \mathrm{C}$, followed by 35 cycles of $40 \mathrm{~s}$ at $94{ }^{\circ} \mathrm{C}$, $40 \mathrm{~s}$ at $53{ }^{\circ} \mathrm{C}$ and $1 \mathrm{~min}$ at $72{ }^{\circ} \mathrm{C}$, and a final extension of $10 \mathrm{~min}$ at $72{ }^{\circ} \mathrm{C}$. PCR reaction condition of TEF1- $\alpha$ was as follows: $5 \mathrm{~min}$ at $94{ }^{\circ} \mathrm{C}$, followed by 35 cycles of $50 \mathrm{~s}$ at $94{ }^{\circ} \mathrm{C}$, $40 \mathrm{~s}$ at $64^{\circ} \mathrm{C}$ and $1 \mathrm{~min}$ at $72{ }^{\circ} \mathrm{C}$, and a final extension of $10 \mathrm{~min}$ at $72^{\circ} \mathrm{C}$. The PCR products were visualized using agarose gel electrophoresis after staining with dyes (TS-GelRed Ver.2, Tsingke Biotechnology Co., Ltd., Beijing, China). Then, the products were sent for sequencing at Sangon Biotech Co. Ltd., Shanghai, China.

\subsection{Sequence Alignment and Phylogenetic Analyses}

Phylogenetic trees were constructed using the sequencing data of T. inusitaticapitatum and the allied reference sequences of closely related Ophiocordycipitaceae species obtained from the GenBank (Table 5). Aschersonia confluens (BCC 7961) and A. paraphysata (BCC 1467) of Clavicipitaceae were used as outgroup taxa. All sequences were assembled and aligned using MAFFT $v 6.8$ [69] and manually edited where necessary in BioEdit version 7.0.9 [70]. Individual alignments were compiled for SSU, LSU, ITS, TEF1- $\alpha$ and RPB2 genes. The optimal substitution model for each gene dataset was determined using MrModeltest 2.3 [71] under the Akaike information criterion (AIC). The results indicated that the GTR $+\mathrm{I}+\mathrm{G}$ model was optimal for all the gene regions. Individual datasets were combined to assemble the combined dataset (gene order: SSU, LSU, ITS, TEF1- $\alpha$ and RPB2). The resulted combined dataset was deposited in the TreeBASE database (http: / / purl.org/phylo/treebase/phylows/study/TB2:S27887?x-access-code= 746eddc746009259527edd3d4c69526b\&format=html, accessed on 10 March 2021). 
Table 5. Voucher information and GenBank accession numbers for samples appearing in the Tolypocladium phylogenetic tree.

\begin{tabular}{|c|c|c|c|c|c|c|}
\hline \multirow{2}{*}{ Taxon } & \multirow{2}{*}{ Strain/Specimen Voucher } & \multicolumn{5}{|c|}{ GenBank Accession Numbers } \\
\hline & & ITS & $28 S$ & $18 S$ & TEF1- $\alpha$ & $R P B 2$ \\
\hline Aschersonia confluens & BCC 7961 & JN049841 & DQ384947 & DQ372100 & DQ384976 & DQ452465 \\
\hline A. paraphysata & BCC 1467 & & DQ̂377987 & DQ̄372090 & DQ̊384967 & DQ452463 \\
\hline Drechmeria gunnii & OSC 76404 & JN049822 & AF 339522 & AF339572 & AY 489616 & DQ̄522426 \\
\hline D. sinensis & CBS 567.95 & MH862540 & AF339545 & AF339594 & DQ522343 & DQ̄522443 \\
\hline D. zeospora ${ }^{\mathrm{ex}}$ & CBS 335.80 & MH861269 & AF339540 & AF339589 & EF469062 & EF469109 \\
\hline Ophiocordyceps gracilis & EFCC 8572 & JN049851 & EF468811 & EF468956 & EF468751 & EF468912 \\
\hline O. heteropoda & EFCC 10125 & JN049852 & EF468812 & EF468957 & EF468752 & EF468914 \\
\hline Paecilomyces lilacinus & CBS 431.87 & AY624188 & EF468844 & & EF468791 & EF468940 \\
\hline Pa. lilacinus ${ }^{\mathrm{ex}}$ & CBS 284.36 & AY624189 & FR775484 & & EF468792 & EF468941 \\
\hline Perennicordyceps cuboidea & NBRC 101740 & JN943331 & JN941417 & JN941724 & KF049684 & \\
\hline Pe. cuboidea & NBRC 100941 & JN943329 & JN941416 & JN941725 & & \\
\hline Pe. paracuboidea & NBRC 101742 & JN943338 & JN941431 & JN941710 & KF049685 & KF049669 \\
\hline Pe. paracuboidea & NBRC 100942 & JN943337 & JN941430 & JN941711 & AB972954 & AB972958 \\
\hline Pe. prolifica & TNS-F-18481 & KF049659 & KF049631 & KF049612 & KF049686 & \\
\hline Pe. prolifica & TNS-F-18547 & KF049660 & KF049632 & KF049613 & KF049687 & KF049670 \\
\hline $\begin{array}{c}\text { Polycephalomyces } \\
\text { aurantiacus }\end{array}$ & MFLU 17-1393 & MG136919 & MG136913 & MG136907 & MG136877 & MG136873 \\
\hline Po. aurantiacus & MFLUCC 172113 & MG136916 & MG136910 & MG136904 & MG136875 & MG136870 \\
\hline Po. marginaliradians & MFLU 17-1582 & MG136920 & MG136914 & MG136908 & MG136878 & MG271931 \\
\hline Po. marginaliradians & MFLUCC $17-2276$ & MG1369 21 & MG136915 & MG136909 & MG136879 & MG271930 \\
\hline Po. nipponicus & NBRC 101406 & JN943301 & JN941388 & JN941753 & & \\
\hline Po. nipponicus & BCC 1682 & KF049664 & KF049638 & KF049620 & KF049694 & MF416463 \\
\hline Po. yunnanensis & YHCPY1005 & KF977848 & KF977848 & KF977848 & KF977850 & KF977854 \\
\hline Po. yunnanensis & YHHPY1006 & KF977849 & KF977849 & KF977849 & KF977851 & KF977855 \\
\hline $\begin{array}{l}\text { Tolypocladium } \\
\text { amazonense }\end{array}$ & VPB179 & KF747267 & & KF747329 & & \\
\hline T. amazonense $e^{\mathrm{ex}}$ & MS308 & & KF747134 & KF747314 & KF747099 & \\
\hline T. capitatum & NBRC 106325 & & JN941402 & JN941739 & AB968598 & AB968559 \\
\hline T. capitatum & NBRC 100997 & & JN941401 & JN941740 & AB968597 & AB968558 \\
\hline T. cylindrosporum & ARSEF 2920 & MG228381 & & & MG228390 & MG228387 \\
\hline T. cylindrosporum & YFCC 1805001 & MK984581 & MK984577 & MK984565 & MK984569 & MK984573 \\
\hline T. endophyticum & MX535 & KF747260 & KF747153 & KF747322 & KF747117 & \\
\hline T. flavonigrum ${ }^{\mathrm{ex}}$ & ВСС 66576 & MN338090 & MN337287 & & MN338495 & \\
\hline T. flavonigrum & BCC 66578 & MN338091 & MN337288 & & MN338496 & \\
\hline T. flavonigrum & BCC66580 & & MN337289 & & MN338497 & \\
\hline T. fractum & OSC 110990 & & DQ518759 & DQ522545 & DQ522328 & DQ522425 \\
\hline T. fumosum & WA18945 & KU925171 & KÜ985053 & & & \\
\hline T. geodes & CBS 126054 & MH864065 & MH875520 & & & \\
\hline T. inflatum & OSC 71235 & JN049844 & EF469077 & EF469124 & EF469061 & EF469108 \\
\hline T. inflatum & CBS 127302 & МH864514 & MH875949 & & & \\
\hline T. inusitaticapitatum & HKAS 112152 & MW537735 & MW537718 & MW537733 & MW507527 & MW507529 \\
\hline T. inusitaticapitatum & HKAS 112153 & MW537736 & MW537719 & MW537734 & MW507528 & MW507530 \\
\hline T. jezoense & txid94205 & AB027365 & AB027365 & AB027319 & & \\
\hline T. longisegmentatum & OSC 110992 & & EF468816 & & & EF468919 \\
\hline T. nubicola & CBS 568.84 & MH861780 & MH873478 & & & \\
\hline T. ophioglossoides & CBS 100239 & KU382155 & KJ878874 & KJ878910 & KJ878958 & \\
\hline T. ophioglossoides & NBRC 8992 & JN943316 & JN941405 & JN941736 & AB968601 & AB968562 \\
\hline T. ovalisporum & CBS 700.92 & AB457006 & & & & \\
\hline T. paradoxum & NBRC 106958 & JN943324 & JN941411 & JN941730 & AB968600 & AB968561 \\
\hline T. paradoxum & NBRC 100945 & JN943323 & JN941410 & JN941731 & AB968599 & AB968560 \\
\hline T. pustulatum & MRL GB6597 & AF389189 & AF389190 & & & \\
\hline T. tropicale & MX338 & KF747259 & KF747149 & KF747318 & KF747113 & \\
\hline T. tropicale ex $^{\text {en }}$ & IQ214 & KF747254 & KF747125 & & KF747090 & \\
\hline T. tundrense & CBS 569.84 & MH861781 & MH873479 & & & \\
\hline T. valliforme & DAOM 196368 & AY245640 & & AY245648 & & \\
\hline
\end{tabular}

New sequencing data are displayed in bold. Specimens of the current study are given in red. Type specimens are in bold; superscript 'ex' indicates ex-type.

Maximum likelihood (ML) analysis was performed using IQ-Tree (http:/ / iqtree.cibiv. univie.ac.at/, accessed on 20 May 2021) [72,73]. The substitution model options for each gene were auto-evaluated according to the provided partition file. Clade support for the ML analysis was assessed using an SH-aLRT test with 1000 replicates [74] and the ultrafast bootstrap (UFB) [75]. In the ML analyses, nodes with support values of SH-aLRT $\geq 80$ and $\mathrm{UFB} \geq 95$ were considered well-supported, those with either SH-aLRT $<80$ or UFB $<95$ were considered weakly supported, and nodes with SH-aLRT $<80$ and UFB $<95$ were considered unsupported.

Bayesian Inference (BI) analysis was carried out in MrBayes v3.2.6 [76]. Gaps were treated as missing data. Four simultaneous Markov Chain Monte Carlo (MCMC) chains were run for 10,000,000 generations and were sampled at every 100th generation until the standard deviation of the split frequencies fell below 0.01 and ESS values > 200. Subsequently, phylogenetic trees were summarized and posterior probabilities (PP) were 
calculated using MCMC by discarding the first $25 \%$ generations as the burn-in phase [77]. Phylogenetic trees were viewed in FigTree v.1.4.4. Nodes with BI posterior probability (BIPP) $>0.90$ were considered to be well supported.

Author Contributions: This study was initiated by F.-M.Y. and K.D.H. Samples were collected by J.-W.L. Morphological observation and description were done by F.-M.Y., K.D.H., K.W.T.C., D.-P.W., S.-M.T., J.-W.L. and L.L., and phylogeny analyses were done by F.-M.Y., K.W.T.C. and Q.Z. The manuscript was mainly drafted by F.-M.Y. with contributions from all other authors. All authors have read and agreed to the published version of the manuscript.

Funding: This research is supported by the National Natural Science Foundation of China, grant "Characterization of roots and their associated rhizosphere microbes in agroforestry systems: ecological restoration in high-phosphorus environment" (Grant No. 31861143002), "Impact of climate change on fungal diversity and biogeography in the Greater Mekong Subregion" (Grant No. RDG6130001), the Open Research Project "Cross-Cooperative Team" of the Germplasm Bank of Wild Species, Kunming Institute of Botany, Chinese Academy of Sciences (Grant No. 292019312511043), Guizhou Science and Technology Planning Project (Guizhou Science and Technology Cooperation Support [2021] General 200) and the Joint Agricultural Program of Yunnan Province (No.2018FG001 032).

Institutional Review Board Statement: Not applicable.

Informed Consent Statement: Not applicable.

Data Availability Statement: The obtained gene sequences were deposited in the NCBI GenBank database. The accession numbers of the obtained sequences are contained within the article and in Table 5.

Acknowledgments: The authors would like to express their sincere thanks to Ling-Sheng Zha (School of Life Sciences, Huaibei Normal University, Huaibei 235000, People's Republic of China) for his help in finding literature and comments on this work; to Shaun Pennycook (Manaaki Whenua-Landcare Research, Private Bag 92170, Auckland 1072, New Zealand) for nomenclatural review; to Jennifer Luangsa-ard (National Center for Genetic Engineering and Biotechnology (BIOTEC), 113 Thailand Science Park, Phahonyothin Rd., Khlong Nueng, Khlong Luang, Pathum Thani 12120, Thailand) for providing detailed information on Tolypocladium flavonigrum.

Conflicts of Interest: The authors declare no conflict of interest.

\section{References}

1. Sun, J.-Z.; Liu, X.-Z.; McKenzie, E.H.; Jeewon, R.; Liu, J.-K.; Zhang, X.-L.; Zhao, Q.; Hyde, K.D. Fungicolous fungi: Terminology, diversity, distribution, evolution, and species checklist. Fungal Divers. 2019, 95, 337-430. [CrossRef]

2. Wijayawardene, N.N.; Hyde, K.D.; Al-Ani, L.K.T.; Tedersoo, L.; Haelewaters, D.; Rajeshkumar, K.C.; Zhao, R.L.; Aptroot, A.; Leontyev, D.V.; Saxena, R.K.; et al. Outline of Fungi and fungus-like taxa. Mycosphere 2020, 11, 1060-1456. [CrossRef]

3. Hyde, K.D.; Norphanphoun, C.; Maharachchikumbura, S.S.N.; Bhat, D.J.; Jones, E.B.G.; Bundhun, D.; Chen, Y.J.; Bao, D.F.; Boonmee, S.; Calabon, M.S.; et al. Refined families of Sordariomycetes. Mycosphere 2020, 11, 305-1059. [CrossRef]

4. Gams, W. Tolypocladium, eine Hyphomycetengattung mit geschwollenen Phialiden. Persoonia 1971, 6, $185-191$.

5. Hodge, K.T.; Krasnoff, S.B.; Humber, R.A. Tolypocladium inflatum is the anamorph of Cordyceps subsessilis. Mycologia 1996, 88, 715-719. [CrossRef]

6. Sung, G.H.; Hywel-Jones, N.L.; Sung, J.M.; Luangsa-ard, J.J.; Shrestha, B.; Spatafora, J.W. Phylogenetic classification of Cordyceps and the clavicipitaceous fungi. Stud. Mycol. 2007, 57, 5-59. [CrossRef] [PubMed]

7. Gams, W. Chaunopycnis alba, gen. et sp. nov., a soil fungus intermediate between Moniliales and Sphaeropsidales. Persoonia 1980, 11,75-79.

8. Quandt, C.A.; Kepler, R.M.; Gams, W.; Araújo, J.P.M.; Ban, S.; Evans, H.C.; Hughes, D.; Humber, R.; Hywel-Jones, N.; Li, Z.; et al. Phylogenetic-based nomenclatural proposals for Ophiocordycipitaceae (Hypocreales) with new combinations in Tolypocladium. IMA Fungus 2014, 5, 121-134. [CrossRef]

9. Mains, E.B. Species of Cordyceps parasitic on Elaphomyces. Bull. Torrey Bot. Club 1957, 84, 243-251. [CrossRef]

10. Kobayasi, Y.; Shimizu, D. Monographic studies of Cordyceps 1, group parasitic on Elaphomyces. Bull. Natl. Sci. Mus. Tokyo 1960, 5, 69-85.

11. Nikoh, N.; Fukatsu, T. Interkingdom host jumping underground: Phylogenetic analysis of entomoparasitic fungi of the genus Cordyceps. Mol. Biol. Evol. 2000, 17, 629-638. [CrossRef]

12. Gazis, R.; Skaltsas, D.; Chaverri, P. Novel endophytic lineages of Tolypocladium provide new insights into the ecology and evolution of Cordyceps-like fungi. Mycologia 2014, 106, 1090-1105. [CrossRef] [PubMed] 
13. Sung, G.H.; Sung, J.M.; Hywel-Jones, N.L.; Spatafora, J.W. A multi-gene phylogeny of Clavicipitaceae (Ascomycota, Fungi): Identification of localized incongruence using a combinational bootstrap approach. Mol. Phylogenet. Evol. 2007, 44, 1204-1223. [CrossRef] [PubMed]

14. Kepler, R.; Ban, S.; Nakagiri, A.; Bischoff, J.; Hywel-Jones, N.; Owensby, C.A.; Spatafora, J.W. The phylogenetic placement of hypocrealean insect pathogens in the genus Polycephalomyces: An application of One Fungus One Name. Fungal Biol. 2013, 117, 611-622. [CrossRef]

15. Quandt, C.A.; Patterson, W.; Spatafora, J.W. Harnessing the power of phylogenomics to disentangle the directionality and signatures of interkingdom host jumping in the parasitic fungal genus Tolypocladium. Mycologia 2018, 110, 104-117. [CrossRef]

16. Quandt, C.A.; Di, Y.; Elser, J.; Jaiswal, P.; Spatafora, J.W. Differential expression of genes involved in host recognition, attachment, and degradation in the mycoparasite Tolypocladium ophioglossoides. G3 Genes Genomes Genet. 2016, 6, 731-741. [CrossRef]

17. Wijayawardene, N.N.; Hyde, K.D.; Rajeshkumar, K.C.; Hawksworth, D.L.; Madrid, H.; Kirk, P.M.; Braun, U.; Singh, R.V.; Crous, P.W.; Kukwa, M.; et al. Notes for genera: Ascomycota. Fungal Divers. 2017, 86, 1-594. [CrossRef]

18. Wang, J.-C.; Zhang, Z.-Z.; Li, C.-L.; Wang, Y. Research Progress of Tolypocladium in Ophiocordycipitaceae. J. Fungal Res. 2019, 1-10. [CrossRef]

19. Maas Geesteranus, R.A. On 'Cordyceps capitata'. Persoonia 1963, 2, 477-482.

20. Ginns, J. Typification of Cordyceps canadensis and C. capitata, and a new species, C. longisegmentis. Mycologia 1988, 80, 217-222. [CrossRef]

21. Zang, M.; Kinjo, N. Notes on the alpine Cordyceps of China and nearby nations. Mycotaxon 1998, 66, $215-229$.

22. Zhang, D.-Z.; Zhou, W.-N.; Wu, S.-H.; Wang, Y.-Z. Macrofungi in Fushan; Council of Agriculture, Executive Office: Taipei, Taiwan, 2000.

23. Bissett, J. Notes on Tolypocladium and related genera. Can. J. Bot. 1983, 61, 1311-1329. [CrossRef]

24. Samson, R.A.; Soares, G.G. Entomopathogenic species of the hyphomycete genus Tolypocladium. J. Invertebr. Pathol. 1984, 43, 133-139. [CrossRef]

25. Wright, D.A.; Cummings, N.J.; Haack, N.A.; Jackson, T.A. Tolypocladium cylindrosporum, a novel pathogen for sheep blowflies. New Zeal. J. Agric. Res. 2009, 52, 315-321. [CrossRef]

26. Xu, W.-S.; LYU, G.-Z.; Jiang, H.; Zhao, Z.-H.; Sun, X.-D.; LYU, S.-Y. Three species of Tolypocladium isolated from forest soil of Changbai mountain. J. Fungal Res. 2012, 10, 143-146.

27. Montalva, C.; Silva, J.J.; Rocha, L.F.N.; Luz, C.; Humber, R.A. Characterization of Tolypocladium cylindrosporum (Hypocreales, Ophiocordycipitaceae) isolates from Brazil and their efficacy against Aedes aegypti (Diptera, Culicidae). J. Appl. Microbiol. 2019, 126, 266-276. [CrossRef] [PubMed]

28. Liang, Z.-Q.; Liu, A.-Y.; Liu, M.-H. Two new records of mycogenous Cordyceps in China. Mycosystema 2003, 22, 159-160.

29. Li, C.; Hywel-jones, N.; Cao, Y.; Nam, S.; Li, Z. Tolypocladium dujiaolongae sp. nov. and its allies. Mycotaxon 2018, 133, 229-241. [CrossRef]

30. Crous, P.W.; Cowan, D.A.; Yilmaz, N.; Larsson, E.; Angelini, C.; Brandrud, T.E.; Dearnaley, J.D.W.; Dima, B.; Dovana, F.; Fechner, N.; et al. Fungal Planet description sheets: 1112-1181. Persoonia 2020, 45, 251-409. [CrossRef]

31. Crous, P.W.; Wingfield, M.J.; Burgess, T.I.; Hardy, G.E.S.J.; Barber, P.A.; Alvarado, P.; Barnes, C.W.; Buchanan, P.K.; Heykoop, M.; Moreno, G.; et al. Fungal Planet description sheets: 558-624. Persoonia 2017, 38, 240-384. [CrossRef] [PubMed]

32. Lin, Q.-Y.; Li, T.-H.; Song, B. Cordyceps guangdongensis sp. nov. from China. Mycotaxon 2008, 103, 371-376.

33. Liang, Z.-Q. Flora Fungorum Sinicorum. Cordyceps; Science Press: Beijing, China, 2007; Volume 32.

34. Kobayasi, Y.; Shimizu, D. Monographic studies of Cordyceps 2, group parasitic on cicadae. Bull. Natl. Sci. Mus. Tokyo 1963, 6, 286-314.

35. Suo, F.-Y.; Huang, L.-D.; Yu, H. Identification and antibacterial effect research of a Tolypocladium strain isolated from sclerotium of Ophiocordyceps gracilis in Xinjiang. China J. Chin. Mater. Med. 2014, 39, 965-971.

36. Imai, S. On a new species of Cordyceps parasitic on Elaphomyces in Japan. Proc. Imp. Acad. 1934, 10, 677-679. [CrossRef]

37. Ke, Y.-H.; Ju, Y.-M. Two rare ophiocordycipitaceous fungi newly recorded in Taiwan. Bot. Stud. 2015, 56. [CrossRef]

38. Barron, G.L. Structure and biology of a new Tolypocladium attacking bdelloid rotifers. Can. J. Bot. 1983, 61, 2566-2569. [CrossRef]

39. Zeng, X.-L.; Yang, W.-S. Cordyceps canadensis a new record in China. Edible Fungi China 1990, 9, 27.

40. Kobayasi, Y.; Shimizu, D. Cordyceps species from Japan 5. Bull. Natl. Sci. Mus. Tokyo Ser. B Bot. 1982, 8, 111-123.

41. Han, Y.-F.; Liang, Z.-Q.; Chu, H.-L. Tolypocladium nubicola, a new record of Tolypocladium in China. J. Fungal Res. $2004,2,50-52$.

42. Sung, J.M.; Choi, Y.S.; Kim, Y.O.; Kim, S.H.; Sung, G.H. Cordyceps species collected by Korean entomopathogenic fungal collection. In Proceedings of the Third Korean-China Joint Symposium for Mycology (The Korean Society of Mycology and Chinese Academy of Sciences), Seoul, Korea, December 1997; The Korean Society of Mycology: Seoul, Korea, 1997 ; pp. 49-60.

43. Lee, T.S.; Yoon, K.H. The Index of Korea-Japan Mushroom Names in Korea; Personal Printing: Seoul, Korea, 2002.

44. Song, B.; Lin, Q.-Y.; Li, T.-H.; Shen, Y.-H.; Li, J.-J.; Luo, D.-X. Known species of Cordyceps from China and their distribution. J. Fungal Res. 2006, 4, 10-26.

45. Möller, C.; Gams, W. Two new hyphomycetes isolated from Antarctic lichens. Mycotaxon 1993, 48, 441-450.

46. Zha, L.-S.; Xiao, Y.-P.; Jeewon, R.; Zou, X.; Wang, X.; Boonmee, S.; Eungwanichayapant, P.D.; McKenzie, E.H.C.; Hyde, K.D.; Wen, T.-C. Notes on the medicinal mushroom chanhua (Cordyceps cicadae (Miq.) Massee). Chiang Mai J. Sci. 2019, 46, $1023-1035$. 
47. Chen, Z.-A.; Li, Z.-Z.; Chen, Y.-P. Jin-Chanhua (A Precious Cordyceps: Isaria cicadae Miq.); Publishing House of Ancient Chinese Medical Books: Beijing, China, 2014.

48. Bills, G.F.; Polishook, J.D.; Goetz, M.A.; Sullivan, R.F.; White, J.F. Chaunopycnis pustulata sp. nov., a new clavicipitalean anamorph producing metabolites that modulate potassium ion channels. Mycol. Prog. 2002, 1, 3-17. [CrossRef]

49. Teng, S.C. Additional fungi from China IV. Sinensia 1936, 7, 752-823.

50. Teng, S.C. Fungi of China; Korf, R.P., Ed.; Mycotaxon Ltd.: Ithaca, NY, USA, 1996; pp. 118-125.

51. Candoussau, F. Un Cordyceps nouveau des Pyrenees Francaises: Cordyceps Rouxii sp. nov. Mycotaxon 1976, IV, 540-544.

52. Li, C.-L. Study of a new species of Tolypocladium. J. Nanjing Univ. (Nat. Sci. Ed.) 1986, 22, 401-407, 592.

53. Zang, M. Two New Tropical Mycotaxon from Yunnan, China. Acta Bot. Yunnanica 2001, 23, $295-297$.

54. Weiser, J.; Matha, V.; Jegorov, A. Tolypocladium terricola sp. n., a new mosquito-killing species of the genus Tolypocladium Gams (Hyphomycetes). Folia Parasitol. 1991, 38, 363-369.

55. Barron, G.L. Two new fungal parasites of bdelloid rotifers. Can. J. Bot. 1981, 59, 1449-1455. [CrossRef]

56. Kobayasi, Y. Miscellaneous notes of fungi (3). J. Jpn. Bot. 1983, 58, 221-224.

57. Sung, G.H.; Poinar, G.O.; Spatafora, J.W. The oldest fossil evidence of animal parasitism by fungi supports a Cretaceous diversification of fungal-arthropod symbioses. Mol. Phylogenet. Evol. 2008, 49, 495-502. [CrossRef]

58. Spatafora, J.W.; Sung, G.H.; Sung, J.M.; Hywel-Jones, N.L.; White, J.F. Phylogenetic evidence for an animal pathogen origin of ergot and the grass endophytes. Mol. Ecol. 2007, 16, 1701-1711. [CrossRef]

59. Bushley, K.E.; Raja, R.; Jaiswal, P.; Cumbie, J.S.; Nonogaki, M.; Boyd, A.E.; Owensby, C.A.; Knaus, B.J.; Elser, J.; Miller, D.; et al. The Genome of Tolypocladium inflatum: Evolution, organization, and expression of the Cyclosporin biosynthetic gene cluster. PLoS Genet. 2013, 9, e1003496. [CrossRef] [PubMed]

60. Quandt, C.A.; Bushley, K.E.; Spatafora, J.W. The genome of the truffle-parasite Tolypocladium ophioglossoides and the evolution of antifungal peptaibiotics. BMC Genom. 2015, 16, 1-14. [CrossRef] [PubMed]

61. Senanayake, I.C.; Rathnayaka, A.R.; Marasinghe, D.S.; Calabon, M.S.; Gentekaki, E.; Lee, H.B.; Hurdeal, V.G.; Pem, D.; Dissanayake, L.S.; Wijesinghe, S.N.; et al. Morphological approaches in studying fungi: Collection, examination, isolation, sporulation and preservation. Mycosphere 2020, 11, 2678-2754. [CrossRef]

62. Kornerup, A.; Wanscher, J.H. Methuen Handbook of Colour, 3rd ed.; Eyre Methuen: London, UK, 1978.

63. Dissanayake, A.J.; Bhunjun, C.S.; Maharachchikumbura, S.S.N.; Liu, J.-K. Applied aspects of methods to infer phylogenetic relationships amongst fungi. Mycosphere 2020, 11, 2652-2676. [CrossRef]

64. White, T.J.; Bruns, T.; Lee, S.J.W.T.; Taylor, J. Amplification and direct sequencing of fungal ribosomal RNA Genes for phylogenetics. PCR Protoc. A Guide Methods Appl. 1990, 18, 315-322. [CrossRef]

65. Rehner, S.A.; Samuels, G.J. Taxonomy and phylogeny of Gliocladium analysed from nuclear large subunit ribosomal DNA sequences. Mycol. Res. 1994, 98, 625-634. [CrossRef]

66. Vilgalys, R.; Hester, M. Rapid genetic identification and mapping of enzymatically amplified ribosomal DNA from several Cryptococcus species. J. Bacteriol. 1990, 172, 4238-4246. [CrossRef] [PubMed]

67. Rehner, S.A.; Buckley, E. A Beauveria phylogeny inferred from nuclear ITS and EF1- $\alpha$ sequences: Evidence for cryptic diversification and links to Cordyceps teleomorphs. Mycologia 2005, 97, 84-98. [CrossRef] [PubMed]

68. Liu, Y.J.; Whelen, S.; Hall, B.D. Phylogenetic relationships among ascomycetes: Evidence from an RNA polymerse II subunit. Mol. Biol. Evol. 1999, 16, 1799-1808. [CrossRef]

69. Katoh, K.; Kuma, K.I.; Toh, H.; Miyata, T. MAFFT version 5: Improvement in accuracy of multiple sequence alignment. Nucleic Acids Res. 2005, 33, 511-518. [CrossRef]

70. Hall, T.A. BIOEDIT: A user-friendly biological sequence alignment editor and analysis program for Windows 95/98/ NT. Nucleic Acids Symp. Ser. 1999, 41, 95-98.

71. Nylander, J.A. MrModeltest 2. Program distributed by the author. Evol. Biol. Cent. Upps. Univ. 2004, 2-4.

72. Nguyen, L.T.; Schmidt, H.A.; Von Haeseler, A.; Minh, B.Q. IQ-TREE: A fast and effective stochastic algorithm for estimating maximum-likelihood phylogenies. Mol. Biol. Evol. 2015, 32, 268-274. [CrossRef] [PubMed]

73. Chernomor, O.; Von Haeseler, A.; Minh, B.Q. Terrace aware data structure for phylogenomic inference from Supermatrices. Syst. Biol. 2016, 65, 997-1008. [CrossRef]

74. Guindon, S.; Dufayard, J.F.; Lefort, V.; Anisimova, M.; Hordijk, W.; Gascuel, O. New algorithms and methods to estimate maximum-likelihood phylogenies: Assessing the performance of PhyML 3.0. Syst. Biol. 2010, 59, 307-321. [CrossRef] [PubMed]

75. Hoang, D.T.; Chernomor, O.; Von Haeseler, A.; Minh, B.Q.; Vinh, L.S. UFBoot2: Improving the ultrafast bootstrap approximation. Mol. Biol. Evol. 2018, 35, 518-522. [CrossRef]

76. Ronquist, F.; Teslenko, M.; Van Der Mark, P.; Ayres, D.L.; Darling, A.; Höhna, S.; Larget, B.; Liu, L.; Suchard, M.A.; Huelsenbeck, J.P. Mrbayes 3.2: Efficient bayesian phylogenetic inference and model choice across a large model space. Syst. Biol. 2012, 61, 539-542. [CrossRef]

77. Huelsenbeck, J.P.; Ronquist, F. MRBAYES: Bayesian inference of phylogenetic trees. Bioinformatics 2001, 17, 754-755. [CrossRef] 